\title{
Research on the Relationship between Internal Control and Financial Performance_- Social Responsibility as the Intermediary Variable
}

\author{
Xian WANG, Shi-Ping GUAN \\ School of Enterprise Management Guangxi University of Science and Technology, \\ Liuzhou 545006, China \\ E-mail:610268609@qq.com
}

\begin{abstract}
This paper chooses the related data of the listed companies from 2011 to 2015 as the research sample and social responsibility as intermediary variable, and analyzes the relationship between internal control and financial performance. The results shows: there is a significant positive correlation between internal control and financial performance; corporate social responsibility has a positive influence on its financial performance; social responsibility plays a strong intermediary role between internal control and financial performance. These conclusions provide bases for strengthening internal control management and the consciousness of social responsibility, improving the financial performance and promoting sustainable development of enterprises.
\end{abstract}

Keywords - Internal control; Social responsibility; Financial performance; Intermediary variable

\section{INTRODUCTION}

In recent years, the term "social responsibility" has been rooted in the development of enterprises. From the first year of 2006 to the year of 2015, the total number of social responsibility reports increased from 32 to 1703 , and the rapid increase. Under the condition of modern market economy, the influence of enterprises on social life is becoming more and more important, and plays an increasingly important role in economic and social development. We see that some enterprises because they do not fulfill their social responsibility and cause serious social consequences, and some companies because of outstanding social responsibility to obtain the recognition of the market, consumers get the favor.

In recent years, from the perspective of internal control, social responsibility to fulfill the perspective of corporate financial performance has become a hot topic of concern to the academic community, but the study did not form a conclusive conclusion. But also has little research on the relationship between internal control, social responsibility and corporate financial performance, and the study of internal control's impact on financial performance with social responsibility as a mediator variable is less. In view of this, this paper, based on the previous research results, improve the research process, social responsibility as the intermediary variable to explore the relationship between internal control and financial performance for enterprises to strengthen internal control management, enhance corporate social responsibility awareness, improve corporate finance Performance, and promote the healthy development of enterprises to provide the basis.

\section{RESEARCH DESIGN}

\section{A. Research Assumptions}

In the study of the relationship between internal control and corporate financial performance, most scholars in our country think that the two are positively correlated, that is, internal control has a positive effect on the company's financial performance For example, Zhang Shuangpeng et al (2011) empirical study of China's internal control of enterprises and their business environment adaptability and the adaptability of corporate performance impact. The results show that companies need to improve the internal control system to adapt to their environment, improve this adaptability can increase business performance. Shao Tingting and Wang Jingfang (2013) show that high efficiency internal control has a significant positive effect on financial performance and supports the strengthening and expansion of internal control. For the enterprise, its internal control is reasonable will be directly reflected in the financial performance level, good internal control will promote the business management more stable development, which will to a certain extent, enhance the financial performance of enterprises, Both are relevant. Therefore, this paper presents hypothesis 1 :

$\mathrm{H} 1$ : Internal control is positively related to financial performance.

Domestic and foreign scholars in the empirical study of the relationship between corporate social responsibility and financial performance, most scholars believe that social responsibility in most cases can promote the growth of financial performance. According to the theory of stakeholders, enterprises to fulfill the social responsibility of different stakeholders, is conducive to enhancing its cooperation effect, reduce transaction costs, to get more public trust and support. At the same time, enterprises to actively fulfill their social responsibility is also invisible for its soft advertising, play a promotional role, that is, enterprises to actively fulfill their social responsibility to enhance the soft power of enterprises, making its visibility in the community to improve, and thus promote corporate sustainability Development, improve the level of financial performance. Therefore, this paper presents hypothesis 2 : 
$\mathrm{H} 2$ : Corporate social responsibility is positively related to financial performance.

The mediating effect is that the influence relationship between variables $(\mathrm{X} \rightarrow \mathrm{Y})$ is not a direct causal chain relationship but is generated by the indirect effect of one or more variables $(\mathrm{M})$. At this point we call $\mathrm{M}$ a mediator variable and $\mathrm{X}$ through $\mathrm{M}$ Indirect effects are called mediating effects. The fundamental purpose of enterprises to strengthen internal control and actively fulfill their social responsibility is to improve financial performance and maximize the value of enterprises, and the internal control of embedded social responsibility can save the transaction cost of the enterprise and help the enterprise to realize the social role, To improve corporate financial performance, to maximize the value of enterprises. Therefore, this paper presents hypothesis 3 :

H3: Corporate social responsibility has some mediating effect between internal control and financial performance.

\section{B. Research Samples and Data}

This paper selects the A-share listed companies in Shanghai and Shenzhen as the research object, and uses the relevant data from 2011 to 2015 as the research sample. (1) Remove all ST samples (2) Remove the relevant data anomalies or missing samples. The financial data of this paper are derived from the WIND database, the internal control and social responsibility data are derived from the DIB internal control and risk management database, and the company's social responsibility report, and use EXCEL to complete the data collation.

\section{Variable Selection}

\section{1) Argument}

The independent variable is internal control. There are many ways to evaluate internal control, such as questionnaire survey, and internal control evaluation system based on internal control objectives. This paper chooses the internal control index of Chinese listed companies developed and researched by Dibo Enterprise Risk Management Technology Co., Ltd., which is an internal control index designed by referring to the research results of internal control index at home and abroad and combining with the present situation of internal control system of listed companies in China System, is the first professional, authoritative internal control index, can objectively and truly reflect the level of internal control of listed companies in China.

\section{2) Dependent Variable}

The variable for this paper is the financial performance of the firm. In the domestic and foreign related research, the scholars use the total assets return rate, the net assets return rate and the TobinQ value to measure the financial performance of the enterprise. Which is a relatively comprehensive financial index, can cover the business efficiency, profitability, financial leverage and other aspects of financial performance, therefore, this paper uses the total return on assets $\mathrm{ROA}$ to measure corporate financial performance.

\section{3) Mediation Variables}

The mediation variable is social responsibility. Foreign scholars have used the reputation index method, content analysis method and KLD index to measure the social responsibility. The scholars of our country mainly divide the social responsibility into multiple dimensions based on the stakeholder theory to measure the social responsibility. This paper uses the scores in the corporate social responsibility report of the listed companies to measure corporate social responsibility, and the social responsibility report of listed companies is composed of shareholders' liability, employee responsibility, supplier, customer and consumer rights, environmental responsibility and social responsibility. Study, respectively, the establishment of two and three indicators of social responsibility to conduct a comprehensive evaluation, with a certain degree of reliability.

\section{4) Control Variables}

Combined with the relevant literature research found that the scale of enterprises, business growth, asset-liability ratio and so on the financial performance of enterprises have a certain impact. Therefore, this paper chooses enterprise scale, enterprise growth and asset liability ratio as control variables.

TABLE I. VARIABLE DEFINITION

\begin{tabular}{|c|c|c|c|}
\hline Variable type & Variable name & Variable symbol & Variable description \\
\hline $\begin{array}{l}\text { Dependent } \\
\text { variable }\end{array}$ & $\begin{array}{c}\text { Financial } \\
\text { Performance }\end{array}$ & ROA & Return On Total Assets \\
\hline $\begin{array}{l}\text { Independent } \\
\text { variable }\end{array}$ & Internal Control & IC & $\begin{array}{c}\text { Dibao China Listed Company Internal Control } \\
\text { Index }\end{array}$ \\
\hline Mediation variable & $\begin{array}{l}\text { Corporate Social } \\
\text { Responsibility }\end{array}$ & CSR & $\begin{array}{c}\text { Corporate Social Responsibility Evaluation Results } \\
\text { of Listed Companies }\end{array}$ \\
\hline \multirow{3}{*}{ Control variable } & Enterprise scale & SIZE & The total assets of the logarithm \\
\hline & Enterprise growth & GROWTH & Main business income growth rate \\
\hline & Assets and liabilities & LEV & Asset liability ratio $=$ total liabilities $/$ total assets \\
\hline
\end{tabular}




\section{Model building}

According to the above assumptions, this paper establishes three regression models:

1) The relationship between internal control and corporate financial performance test model

$$
\begin{array}{r}
R O A=\beta_{0}+\beta_{1} I C+\beta_{2} S I Z E+ \\
\beta_{3} G R O W T H+\beta_{4} L E V+\varepsilon
\end{array}
$$

2) Social Responsibility and Corporate Financial Performance Test Model

$$
\begin{array}{r}
R O A=\beta_{0}+\beta_{1} C S R+\beta_{2} S I Z E+ \\
\beta_{3} G R O W T H+\beta_{4} L E V+\varepsilon
\end{array}
$$

3) Social responsibility to the internal control and financial performance intermediary test model

$$
\begin{gathered}
R O A=\beta_{0}+\beta_{1} I C+\beta_{2} \mathrm{CSR}+\beta_{3} S I Z E+ \\
\beta_{4} G R O W T H+\beta_{5} L E V+\varepsilon
\end{gathered}
$$

\section{EMPIRICAL ANALYSIS}

\section{A. Descriptive statistical Analysis}

In this paper, the data collected using SPSS21.0 descriptive statistics, the results shown in Table 2 below:

TABLE II. VARIABLE DESCRIPTIVE STATISTICS

\begin{tabular}{ccccc}
\hline & average value & Maximum value & Minimum value & Standard deviation \\
\hline ROA & 0.0670 & 1.6513 & -0.7928 & 0.0796 \\
IC & 713.85 & 995.36 & 33.52 & 98.97 \\
CSR & 27.25 & 90.84 & -15.17 & 18.48 \\
SIZE & 21.91 & 28.51 & 17.39 & 1.32 \\
GROWTH & 0.1449 & 7.7805 & -0.9590 & 0.4131 \\
LEV & 0.4305 & 2.3940 & 0.0071 & 0.2247 \\
\hline
\end{tabular}

The total return on assets ROA is 1.6513 , the minimum is -0.7928 , the mean is 0.0670 , indicating that the overall level of financial performance of listed companies is low. The maximum value of the internal control IC is 995.36 , the minimum is 33.52 , the standard deviation is 98.97 , and the mean is 713.8512 . Indicating that the company's internal control level varies, the difference is very large, but its mean is 713.8512 , indicating that the whole, most of the listed companies or more emphasis on internal control. Corporate social responsibility CSR is the maximum value of 90.84 , the minimum is -15.17 , the mean is 27.25 , the standard deviation is 18.48 , indicating that the listed company's overall level of corporate social responsibility is low, The gap between the

\begin{tabular}{|c|c|c|c|c|c|c|}
\hline & $\overline{\mathrm{ROA}}$ & IC & $\overline{\mathrm{CSR}}$ & $\overline{\text { SIZE }}$ & GROWTH & $\overline{\mathrm{LEV}}$ \\
\hline $\mathrm{ROA}$ & 1 & & & & & \\
\hline IC & $0.421 * * *$ & 1 & & & & \\
\hline CSR & $0.433 * * *$ & $0.232 * * *$ & 1 & & & \\
\hline SIZE & -0.041 & $0.519 * * *$ & $0.101 * * *$ & 1 & & \\
\hline GROWTH & $-0.086^{*}$ & $0.067 * *$ & 0.058 & $0.241 * * *$ & 1 & \\
\hline LEV & $-0.465 * * *$ & 0.047 & $-0.198 * * *$ & $0.397 * * *$ & $0.067 * *$ & 1 \\
\hline
\end{tabular}
level of corporate social responsibility

\section{B. Correlation Analysis}

In this paper, the use of SPSS21.0 variables related analysis, the results shown in Table 3 below:

TABLE III. PEARSON CORRELATION ANALYSIS RESULTS

Financial performance indicators ROA are related to most of the variables. The correlation coefficients between ROA and independent variable IC and CSR are positive, and the significance level is $0.1 \%$. ROA has a negative correlation with the asset-liability ratio LEV, and the level of $0.1 \%$ is significant. ROA was negatively correlated with GROWTH, and the significance level was $5 \%$, while the relationship between ROA and firm size was not significant. In the explanatory variables, we can find that the absolute values of the correlation coefficients between them are not more than 0.5, and Hossain et al. found that the correlation coefficient between the independent variables did not have a significant effect on the multiple linear regression, so we can infer that there is no multiple collinearity between the independent variables.

C. Regression Analysis

1) Internal Control and Corporate Financial Performance Regression Analysis

According to the internal control and corporate financial performance model, the sample data for multiple regression, the results shown in Table 4: 
TABLE IV. INTERNAL CONTROL AND CORPORATE FINANCIAL PERFORMANCE RETURN RESULTS

\begin{tabular}{|c|c|c|c|c|c|}
\hline \multirow[t]{2}{*}{ variable } & \multicolumn{2}{|c|}{$\begin{array}{c}\text { Nonstandard regression } \\
\text { coefficient }\end{array}$} & \multirow[t]{2}{*}{$\begin{array}{c}\text { Standard regression } \\
\text { coefficient }\end{array}$} & \multirow[t]{2}{*}{$\mathrm{T}$} & \multirow[t]{2}{*}{ Significance } \\
\hline & B & Standard error & & & \\
\hline$\beta$ & 1.678 & 0.132 & & 7.789 & 0.000 \\
\hline IC & 0.332 & 0.042 & 0.298 & 6.874 & 0.000 \\
\hline SIZE & 0.723 & 0.062 & 0.695 & 2.413 & 0.021 \\
\hline GROWTH & 0.433 & 0.003 & 0.412 & 3.089 & 0.003 \\
\hline \multirow[t]{2}{*}{ LEV } & -0.457 & 0.006 & -0.409 & -1.719 & 0.045 \\
\hline & & $4.078^{* * *}$ & $\mathrm{R}^{2}=0.734$ & & \\
\hline
\end{tabular}

According to the results of the regression analysis in Table 4, the F statistic of the model is 244.078, the significance level is $\mathrm{Sig}=0.000$, and the explanatory power of the model is better. There was a significant positive correlation between internal control and corporate financial performance at $1 \%$ level. The adjusted R2 was 0.734 , indicating that internal control explained $73.4 \%$ of corporate financial performance. The correlation coefficient is 0.298 , the significance level is 0.000 , which shows that there is a significant positive correlation between internal control and financial performance. It can be concluded that hypothesis 1 is true. The scale and growth of the enterprises in the control variables are positively correlated with the financial performance of the enterprises, indicating that the size and growth of the listed companies are the main factors of the company's profitability. And the asset-liability ratio is negatively correlated with the financial performance of the enterprise, indicating that the financial expenses are the burden of the development of the company, which reduces the financial performance level.

2) Social Responsibility and Corporate Financial Performance Regression Analysis

According to the corporate social responsibility and corporate financial performance model, the sample data for multiple regression, the results shown in Table 5:

TABLE V. CORPORATE SOCIAL RESPONSIBILITY AND CORPORATE FINANCIAL PERFORMANCE RETURN RESULTS

\begin{tabular}{clllll}
\hline \multirow{2}{*}{ variable } & \multicolumn{2}{c}{ Nonstandard regression coefficient } & $\begin{array}{c}\text { Standard regression } \\
\text { coefficient }\end{array}$ & $\mathrm{T}$ & Significance \\
\cline { 2 - 3 }$\beta$ & -3.235 & 0.198 & & -2.336 & 0.003 \\
CSR & 0.112 & 0.043 & 0.101 & 2.989 & 0.000 \\
SIZE & 0.423 & 0.053 & 0.341 & 7.923 & 0.000 \\
GROWTH & 0.386 & 0.017 & 0.783 & 2.978 & 0.002 \\
LEV & -0.412 & 0.032 & -0.192 & -1.986 & 0.000 \\
\hline \multicolumn{5}{r}{} \\
\hline
\end{tabular}

According to the results of the regression in Table 5, the $\mathrm{F}$ statistic of the model is 10.783 and the significance level Sig $=0.047$. The model has some explanatory power. There was a significant positive correlation between corporate social responsibility and corporate financial performance at $0.1 \%$ level. The adjusted R2 was 0.725 , indicating that corporate social responsibility explained $72.5 \%$ of corporate financial performance. The correlation coefficient is 0.101 , the significance level is 0.000 , which shows that social responsibility has a significant positive correlation with financial performance. It can be concluded that hypothesis 2 is established.

3) Internal Control, Social Responsibility and Financial Performance Regression Analysis

According to the social responsibility of the internal control and financial performance intermediary model, the sample data for multiple regression, the results shown in Table 6 
TABLE VI. INTERNAL CONTROL, CORPORATE SOCIAL RESPONSIBILITY AND CORPORATE FINANCIAL PERFORMANCE RETURN RESULTS

\begin{tabular}{|c|c|c|c|c|c|}
\hline \multirow{2}{*}{ variable } & \multicolumn{2}{|c|}{ Nonstandard regression coefficient } & \multirow{2}{*}{$\begin{array}{c}\text { Standard regression } \\
\text { coefficient }\end{array}$} & \multirow{2}{*}{$\mathrm{T}$} & \multirow{2}{*}{ Significance } \\
\hline & $\mathrm{B}$ & Standard error & & & \\
\hline$\beta$ & 2.013 & 0.996 & & 1.467 & 0.007 \\
\hline IC & 0.287 & 0.783 & 0.026 & 2.891 & 0.042 \\
\hline CSR & 0.017 & 0.049 & 0.014 & 2.851 & 0.046 \\
\hline SIZE & 1.683 & 0.051 & 0.012 & 3.214 & 0.001 \\
\hline GROWTH & 0.804 & 0.014 & 0.346 & 2.013 & 0.000 \\
\hline \multirow[t]{2}{*}{ LEV } & -0.019 & 0.033 & -0.132 & -2.904 & 0.000 \\
\hline & & $\mathrm{F}=9.682^{* * * *}$ & $\mathrm{R}^{2}=0.698$ & & \\
\hline
\end{tabular}

According to the results of the regression in Table 5, we can see that the F statistic of the model is 9.682 and the significance level $\mathrm{Sig}=0.048$. The model has some explanatory power. The level of internal control is still significantly positively correlated with the financial performance of the firm, but by comparing Table 4 with Table 6, the regression coefficient is reduced from 0.298 to 0.026 and the significance level is reduced from below $0.1 \%$ to below 5\%, combined with social responsibility In the analysis of corporate financial performance regression analysis, we can conclude that the increase in the impact of internal controls on corporate financial performance has increased as part of social variables, which suggests that social responsibility plays a part between internal control and corporate financial performance Mediation effect, which can be concluded assuming that the establishment of 3 .

\section{CONCLUSION}

From the regression analysis of the previous section, we can draw the following conclusions: (1) The level of internal control is positively related to the financial performance of the firm, that is, the higher the internal control level is, the higher the financial performance is. As a result, companies can strengthen their internal control to improve their financial performance. (2) Corporate social responsibility has a positive impact on its financial performance, so the positive performance of corporate social responsibility can also enhance its financial performance. (3) When the social responsibility variables enter the internal control and corporate financial performance model, the impact of internal control on corporate financial performance has declined significantly, indicating that social responsibility has played a mediating effect between internal control and corporate financial performance. Therefore, enterprises in strengthening the construction of internal control should also be actively implement the concept of social responsibility into the internal control system, will help improve the level of corporate financial performance and promote sustainable development of enterprises.

\section{REFERENCES}

[1] Shao Tingting, Wang Jingfang. A Study on the Im-pact of Enterpr ise Internal Control Efficiency on Financial Performance - An E mpirical Test from Listed Companies in Pharmaceutical Manufac turing Industry[J]. Productivity Research, 2013, 09:183- 185+196.
[2] Zeng Jieqiong. The Impact of Internal Control of Public Listed C ompanies on Financial Performance [J]. Busine-ss Economy, 2014, 09:38- 39 .

[3] Li Guosheng, Du Yan. An Empirical Study on Fin-ancial Perform ance and Internal Control Index of Listed Companies Based on P anel Data [J]. Enterpri-se Economy, 2015, 07:74- 78.

[4] Ye Zi. Empirical Study on the Relationship of Internal Control an d Enterprise Performance--from the Aspect of Internal Auditing [D]. Beijing Jiaotong University, 2011.

[5] Demski J S. Decision-Performance Control [J]. Account-ing Revie w, 1969, 44(4):669-679.

[6] Ge W, Mcvay S. The Disclosure of Material Weaknesses in Intern al Control after the Sarbanes_Oxley Act [J]. Social Science Elect ronic Publishing, 2008, 19(3):6439-52.

[7] Franklin M. Sarbanes Oxley Section 404: Can material weakness be predicted and modeled? An examination of the variables of the ZETA model in prediction of mate-rial weakness [J]. Dissertation s \& Theses - Gradworks, 2007.

[8] Zhilkina Anna N. Enterprise financial management qual-ity contro $1[\mathrm{C}] / /$ International Conference on Management Science and Engin eering, 2008. Icmse 2008. Conferenc-e Proceedings. IEEE, 2008:1 101-1104.

[9] Jiang Hongyun,Jing Shanshan. A Study on the Correlati-on betwe en Corporate Social Responsibility and Financi-al Performance A Case Study of Pharmaceutical Man-ufacturing Listed Companie s [J]. Friends of Accounting, 2013, 01:49- 52.

[10] Liu L Ujing, Chen Xiaoming. A Study on the Impact of Social R esponsibility on Financial Performance [J]. Stati-stics \& Decision, 2010, 14:149- 151.

[11] Fan Qi. A Study on the Correlation between Social Res-ponsibilit $y$ and Financial Performance of Listed Compa-nies in Central Ent erprises [J]. Finance and Accounting Monthly, 2013, 12:25- 28.

[12] Moskowitz, M. Choosing Socially Responsible Stocks [J]. Busines s and Society Review, 1972, 1, 72-75.

[13] Choi J S, Kwak Y M, Choe C. Corporate Social Respo-nsibility a nd Corporate Financial Performance: Evidence from Korea [J]. Au stralian Journal of Management, 2010, 35(3):291-311.

[14] Simpson W G, Kohers T. The Link between Corporate Social and Financial Performance: Evidence from the B-anking Industry [J]. Journal of Business Ethics, 2001, 35(2):97-109.

[15] Papania L, Shapiro D M, Peloza J. Social impact as a measure o $\mathrm{f}$ fit between firm activities and stakeholder e-xpectations [J]. Inte rnational Journal of Business Gover-nance \& Ethics, 2008, volum e 4(1):3-16(14).

[16] Li Wei, Teng Yun. A Study on the Relationship between Corporat e Social Responsibility and the Effectiveness of Internal Control [J]. Research on Financial and Economic Issues, 2015, 08:105- 10 9.

[17] Qi Peng, Shang Yin. Research on Internal Control Based on Corp orate Social Responsibility [J] Enterprise Econo-my, 2015, 04:45- 
48.

[18] Wang Haibing, Liu Sha, Han Bin. The Effect of Internal Control and Financial Performance on Corporate Social Responsibility--An Empirical Analysis Based on Listed Companies of A-Share [J]. Taxation and Economy, 2015, 06:1- 9.

[19] Tian Lijun, Chen Tiantian. Internal Control, Social Resp-onsibility and Corporate Performance [J]. Journal of Cho-ngqing University (Social Science Edition), 2015, 02:75- 82. 